Pesq. Vet. Bras. 28(1):82-86, janeiro 2008

\title{
Detection and phylogenetic analysis of porcine enteric calicivirus, genetically related to the Cowden strain of sapovirus genogroup III, in Brazilian swine herds ${ }^{1}$
}

\begin{abstract}
Aline F. Barry ${ }^{2 *}$, Alice F. Alfieri² and Amauri A. Alfieri ${ }^{2}$
ABSTRACT.- Barry A.F, Alfieri A.F. \& Alfieri A.A. 2008. Detection and phylogenetic analysis of porcine enteric calicivirus, genetically related to the Cowden strain of sapovirus genogroup III, in Brazilian swine herds. Pesquisa Veterinária Brasileira 28(1):82-86. Laboratório de Virologia Animal, Departamento de Medicina Veterinária Preventiva, Centro de Ciências Agrárias, Universidade Estadual de Londrina, Campus Universitário, Londrina, PR 86051-990, Brazil. E-mail: alinebarry@uol.com.br

Sapovirus of the Caliciviridae family is an important agent of acute gastroenteritis in children and piglets. The Sapovirus genus is divided into seven genogroups (G), and strains from the GIII, GVI and GVII are associated with infections in swine. Despite the high prevalence in some countries, there are no studies related to the presence of porcine enteric sapovirus infections in piglets in Brazil. In the present study, 18 fecal specimens from piglets up to 28 days were examined to determine the presence of sapovirus genome by RT-PCR assay, using primers designed to amplify a $331 \mathrm{bp}$ segment of the RNA polymerase gene. In $44.4 \%(8 / 18)$ of fecal samples, an amplified DNA fragment was obtained. One of these fragments was sequenced and submitted to molecular and phylogenetic analysis. This analysis revealed high similarity, with nucleotides (87\%) and amino acids (97.8\%), to the Cowden strain, the GIII prototype of porcine enteric calicivirus. This is the first description of sapovirus in Brazilian swine herds.
\end{abstract}

INDEX TERMS: Swine; piglets, diarrhea, calicivirus, Sapovirus.

RESUMO.- [Detecção e análise filogenética do calicivírus entérico suíno, geneticamente relacionado com a estirpe Cowden do genogrupo III do sapovírus, em rebanhos brasileiros.] O sapovírus classificado na família Caliciviridae é um importante causador de gastroenterite aguda em crianças e leitões. O gênero Sapovirus é dividido em sete genogrupos (G), sendo que as estirpes dos GIII, GVI e GVII estão associadas com infecção em suínos. Apesar da alta prevalência da infecção em alguns países, ainda não existem estudos referentes à presença do calicivírus entérico suíno nos rebanhos brasileiros. No presente estudo 18 amostras de fezes de leitões com até 28 dias foram avaliadas pela RT-PCR para a presença do

\footnotetext{
${ }^{1}$ Received on September 20, 2007.

Accepted for publication on November 21, 2007.

${ }^{2}$ Laboratório de Virologia Animal, Departamento de Medicina Veterinária Preventiva, Centro de Ciências Agrárias, Universidade Estadual de Londrina, Campus Universitário, Londrina, PR 86051-990, Brazil. *Author for correspondence: alinebarry@uol.com.br
}

genoma do sapovírus, utilizando os primers desenvolvidos para amplificar um segmento de $331 \mathrm{pb}$ do gene da RNA polimerase viral. Em 44,4\% (8/18) das amostras foi amplificado um fragmento de DNA. Um desses amplicons foi seqüenciado e pela análise molecular e filogenética foi verificada similaridade de $87 \%$ em nucleotídeos e $97,8 \%$ em aminoácidos com a estirpe Cowden, protótipo do GIII. Esta é a primeira descrição do sapovírus em rebanhos suínos brasileiros.

TERMOS DE INDEXAÇÃO: Suínos, leitões, diarréia, calicivírus, Sapovirus.

\section{INTRODUCTION}

Caliciviruses are small, non-enveloped viruses with 27$35 \mathrm{~nm}$ in diameter. Their genome consists of a singlestranded poly-adenylated RNA molecule with positive polarity of 7.4 to $8.3 \mathrm{~Kb}$, that encodes a major (VP1) and a minor (VP2) structural protein, and nonstructural proteins including RNA dependent RNA polymerase (RdRp) (ICTVdB). Four genera have been established in the 
Caliciviridae family: Vesivirus, Lagovirus, Norovirus, and Sapovirus (Green et al. 2000). In animals, lagoviruses and vesiviruses are associated with a number of important hemorrhagic, respiratory, and vesicular diseases. Norovirus (NoV) and sapovirus (SaV) are associated with gastroenteritis in humans and animals (Kapikian et al. 1972, Madeley \& Cosgrove 1976, Flynn et al. 1988).

Based on the sequence of the capsid gene, the Sapovirus genus can be classified into seven genogroups: GI, GII, GIV, and GV that infect humans; and GIII, GVI and GVII that infect pigs. The Cowden strain causes diarrhea and intestinal lesions in pigs, and is considered the prototype of the GIII, while the other porcine genogroups have JJ681 and K7/JP as main strains, respectively (Guo et al. 1999, Farkas et al. 2004, Wang et al. 2005, Yin et al. 2006). In addition to its putative importance as a porcine pathogen, there is the possibility of the zoonotic potential for the virus. Despite the high genetic variability of the SaV strains, intragenogroups and intergenogroups recombination have already been described, suggesting that recombination between porcine and human strains may also occur (Katayama et al. 2004, Hansman et al. 2005, Wang et al. 2005).

Porcine enteric caliciviruses were detected in pigs stool samples only in a few countries from Europe (Reuter et al. 2007), America (Wang et al. 2005, Martínez et al. 2006) and Asia (Kim et al. 2006, Yin et al. 2006). However, the association between infection and diarrhea was not verified in all studies, possibly due the high genetic variability of the SaV strains, in which not all strains lead to the development of enteric disease. In this study, we describe the detection of SaV in stool samples from piglets in Brazilian swine farms by RT-PCR assay. Additionally, comparing by phylogenetic analysis with other published SaV strains, we classify the partial RdRp nucleotide sequence obtained from the sequencing of one sample.

\section{MATERIALS AND METHODS}

Eighteen stool samples were collected from piglets aging up to 28 days from three Brazilian swine farms (G, L, M) located in Mato Grosso do Sul (MS) State (S $19^{\circ} 23^{\prime} 43^{\prime \prime}$ W 54 $33^{\prime} 59^{\prime \prime}$ ), during 2004. Four age groups were included: 1 to $7(n=3), 8$ to $14(n=2), 15$ to $21(n=6)$, and 22 to $28(n=7)$ days old. Thirteen animals had diarrhea and five were asymptomatic.

Viral RNA was extracted from $10 \%$ to $20 \%(\mathrm{w} / \mathrm{v})$ of fecal suspensions in PBS using a combination of phenol/chloroform/ isoamyl alcohol and silica/guanidinium isothiocyanate method according to Alfieri et al. (2006). The primer pair used (p289/ 290) was designed by Jiang et al. (1999) to amplify a 319 or $331 \mathrm{bp}$ fragment from RdRp gene of NoV or SaV, respectively. Reverse transcription reaction was performed in a $20 \mu \mathrm{l}$ final volume containing $5 \mu \mathrm{l}$ of extracted RNA, $1 \mu \mathrm{l}$ (20pmol) of p289 reverse primer and $4 \mu \mathrm{l}$ of ultra pure RNase free water, that was denaturated at $97^{\circ} \mathrm{C}$ for $5 \mathrm{~min}$. After, it was placed on ice for $5 \mathrm{~min}$, and $10 \mu \mathrm{l}$ of the RT mix $(1 \times \mathrm{RT}$ buffer, $0.1 \mathrm{mM}$ of dNTP, $10 \mathrm{mM}$ DTT, $100 \mathrm{U}$ of M-MLV reverse transcriptase and ultrapure sterile water) was added and incubated at $42^{\circ} \mathrm{C}$ for $30 \mathrm{~min}$ followed by enzyme inactivation at $95^{\circ} \mathrm{C}$ for $5 \mathrm{~min}$. The PCR had a total of $50 \mu \mathrm{l}$ [ $8 \mu \mathrm{l}$ of the RT reaction, $1.5 \times \mathrm{PCR}$ buffer, $2 \mathrm{mM}$ $\mathrm{MgCl}_{2}, 0.2 \mathrm{mM}$ of each dNTP, $1 \mu \mathrm{l}$ (20pmol) of each primer, 2.5 units Platinum Taq DNA polymerase and ultrapure RNase free water]. Thermocycler temperatures included one step at $94^{\circ} \mathrm{C}$ for $3 \mathrm{~min}, 40$ cycles at $94^{\circ} \mathrm{C}$ for $30 \mathrm{~s}, 49^{\circ} \mathrm{C}$ for $1 \mathrm{~min} 20 \mathrm{~s}$, and $72^{\circ} \mathrm{C}$ for $1 \mathrm{~min}$, and a final step at $72^{\circ} \mathrm{C}$ for $10 \mathrm{~min}$. The RT-PCR products were analyzed by electrophoresis in a $2 \%$ agarose gel stained with ethidium bromide and visualized under UV light.

A stool sample from a child with NoV infection detected by RT-PCR assay and electron microscopy was used as positive control and ultrapure water as negative control.

All samples included in the study were previously tested by silver stained polyacrylamide gel electrophoresis (SSPAGE) to the presence of rotaviruses, being only one positive to group $A$ rotaviruses (GAR).

The PCR amplicon was purified using GFX ${ }^{\text {TM }}$ PCR DNA and Gel Band Purification Kit (GE Healthcare, USA), and sequenced in MegaBACE ${ }^{\mathrm{TM}} 1000$ and Thermo Sequenase ${ }^{\mathrm{TM}}$ II DNA Polymerase, DYEnamic ${ }^{\mathrm{TM}}$ ET Dye Terminator Kit (GE Healthcare, USA) using the forward and reverse primers.

Sequence editing was performed with Phred and CAP3 softwares (http://adenina.biomol.unb.br/phph/). The translation and verification of conserved motifs was done by using Gene Runner version 3.05. Similarity searches were carried out by using BLAST (http://www.ncbi.nlm.nih.gov/) followed by multiple alignments by CLUSTAL W (version1.4) and sequence identity matrix using BioEdit v7.0.5.3. Phylogenetic distances and tree were generated by using MEGA v3.1 software.

\section{RESULTS AND DISCUSSION}

SaVs were detected by RT-PCR assay in $44.4 \%$ (8/18) of stool samples analyzed (Fig.1). Two samples were from farm G (both from 22 to 28-day-old diarrheic piglets), one from farm $L$ (22 to 28-day-old asymptomatic piglet) and the other five from farm $\mathrm{M}$ (two from 15 to 21-day-old diarrheic piglets and three from 22 to 28-day-old piglets, one of them diarrheic). In summary, from the eight RTPCR amplicons with the 331 bp expected size, five $(62.5 \%)$ were from diarrheic piglets. One diarrheic stool sample from farm $\mathrm{G}$ that was positive to $\mathrm{SaV}$, was also positive to GAR in ssPAGE.

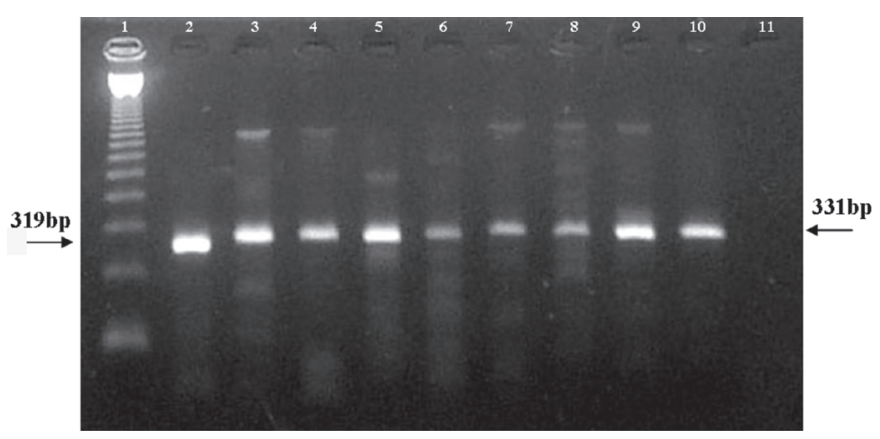

Fig.1. Ethidium bromide stained agarose gel electrophoresis of sapovirus polymerase gene amplified with primer pair p289/ p290 by RT-PCR assay, from piglet stool samples. Lane 1, 123 bp ladder; lane 2 human norovirus with 319 bp; lanes 3 to 10 porcine sapovirus with $331 \mathrm{bp}$; lane 11 negative control (ultrapure water). 
The number of stool samples tested was relatively low to perform statistical tests in order to associate the presence of SaV and clinical signs of diarrhea. In addition, piglets in the beginning and in the end of the infection can show viral shedding without clinical signs. Stool samples from these piglets can increase de number of SaV positive samples in asymptomatic animals leading to wrongs conclusions.

One sample (BRA29-MS/04, GenBank accession number EF183480), from a 22 to 28-day-old diarrheic piglet from farm $\mathrm{G}$, was sequenced. When the obtained sequence was compared to other sequences by BLAST, it was observed a high similarity with porcine SaVs. Before proceeding with the analysis, the sequence was translated and the presence of GLPSG and YGDD RdRp conserved motifs was verified.

To classify the Brazilian sequence, BRA29-MS/04 was aligned with 17 GenBank published SaV sequences including members of all clusters from the seven genogroups, and with 13 strains, from other countries in which the porcine SaV were described. To perform the molecular analysis, the primers sequences were excluded, resulting in a 286 nucleotides fragment. The intra-genogroup distance (overall average of 0.36) was compared to investigate whether BRA29-MS/04 was a Glll strain. Phylogenetic distances based on nucleotides alignments in that partial RdRp gene ranged from 0.03 to 0.33 between members of the same genogroup. Houston7-1181/90 strain, the GIV prototype, had lower distance with GII members and was not included in this analysis. BRA29MS/04 had 0.13 of nucleotide distance with Cowden strain. The distance between the Brazilian strain and new porcine genogroups (GVI and GVII) ranged from 0.45 to 0.50 (data not shown), being above the distance of members from the same genogroup.

Schuffenecker et al. (2001) comparing distances between 11 SaVs strains in five different regions of the genome (RdRp, 3'ORF, capsid overlap, 3'UTR, and capsid) verified that the same genogroups and genetic clusters organization were maintained throughout the genomic regions examined. A similar study was performed in which 17 sequences were classified in nine genetic clusters and five genogroups according to the capsid gene sequence. However, the same organization was not observed to all strains analyzed in the RdRp gene (Farkas et al. 2004). Despite these different results on classifying based on the RdRp gene, the GIII Cowden strain was identified in these two studies as one clearly distinct genogroup either in RdRp partial gene or in capsid gene, being the difference in organization limited to a few human SaV strains. In this way, the classification based on this 286 bp of RdRp gene was enough to classify, at least in genogroup, a SaV strain.

When compared with the prototypes strains from the seven SaV genogroups, BRA29-MS/04 showed the highest identity with the Cowden strain $(87 \%)$ (Table 1). Nucleotide identity with strains from Venezuela (Aragua/ 1999, Miranda1/2001 and Yaracuy/1999), Hungary (Id3/ 2005), Korea (Korean6802 and Korean10802), The Netherlands (PECIVA20, PECIVA36 and SWECI/VA10) and North-America [LL14, JJ259/00 and MM280/03 (excluding QW19, classified as human GII)] ranged from 72.2 to $89.4 \%$ (Wang et al. 2005, Kim et al. 2006, Martínez et al. 2006, Reuter et al. 2007). It was not verified higher similarity among strains from near geographic areas included in the study, since the identity of BRA29-MS/04 with other American strains (USA and Venezuela) was not higher than with strains from other continents. The amino acid analysis (95aa) revealed $97.8 \%$ identity between BRA29-MS/04 and the Cowden strain, whereas the similarity with the others porcine genogroups were 41 and $45.2 \%$ to GVI and GVII, respectively (data not shown). Based on distance, identity and phylogenetic analysis BRA29-MS/04 was classified as a strain from GIII (Fig.2).

Table 1. Nucleotide sequence identity matrix of partial RdRp gene (286 nt) between BRA29-MS/04 wild-type sapovirus strain, and prototype sapovirus strains, representing all clusters into seven genogroups

\begin{tabular}{cccccccccccccccc}
\hline $\begin{array}{c}\text { Genogroup/ } \\
\text { cluster }\end{array}$ & Strain & BRA29 & Sapp & Park & Mex14917 Lond & Mex340 & Cruise ship Cowden Hou7-1181 Arg39 JJ681 & K7/JP \\
\hline & BRA29-MS/04 & ID & 0.552 & 0.601 & 0.58 & 0.597 & 0.59 & 0.608 & 0.87 & 0.594 & 0.548 & 0.531 & 0.5 \\
GI/1 & Sapporo/82 & 0.552 & ID & 0.671 & 0.723 & 0.646 & 0.646 & 0.646 & 0.562 & 0.636 & 0.608 & 0.493 & 0.444 \\
GI/2 & Parkville/94 & 0.601 & 0.671 & ID & 0.73 & 0.657 & 0.678 & 0.678 & 0.604 & 0.65 & 0.583 & 0.531 & 0.468 \\
GI/3 & Mexico14917 & 0.58 & 0.723 & 0.73 & ID & 0.688 & 0.646 & 0.667 & 0.573 & 0.671 & 0.59 & 0.513 & 0.468 \\
GII/1 & London/92 & 0.597 & 0.646 & 0.657 & 0.688 & ID & 0.793 & 0.783 & 0.594 & 0.765 & 0.573 & 0.503 & 0.475 \\
GII/2 & Mexico340/90 & 0.59 & 0.646 & 0.678 & 0.646 & 0.793 & ID & 0.79 & 0.597 & 0.79 & 0.58 & 0.51 & 0.506 \\
GII/3 & Cruise ship/00 & 0.608 & 0.646 & 0.678 & 0.667 & 0.783 & 0.79 & ID & 0.594 & 0.769 & 0.58 & 0.534 & 0.5 \\
GIII & Cowden & 0.87 & 0.562 & 0.604 & 0.573 & 0.594 & 0.597 & 0.594 & ID & 0.587 & 0.566 & 0.538 & 0.496 \\
GIV & Houston7-1181/90 & 0.594 & 0.636 & 0.65 & 0.671 & 0.765 & 0.79 & 0.769 & 0.587 & ID & 0.541 & 0.524 & 0.486 \\
GV & Argentina39 & 0.548 & 0.608 & 0.583 & 0.59 & 0.573 & 0.58 & 0.58 & 0.566 & 0.541 & ID & 0.451 & 0.454 \\
GVI & JJ681 & 0.531 & 0.493 & 0.531 & 0.513 & 0.503 & 0.51 & 0.534 & 0.538 & 0.524 & 0.451 & ID & 0.653 \\
GVII & K7/JP & 0.5 & 0.444 & 0.468 & 0.468 & 0.475 & 0.506 & 0.5 & 0.496 & 0.486 & 0.454 & 0.653 & ID
\end{tabular}




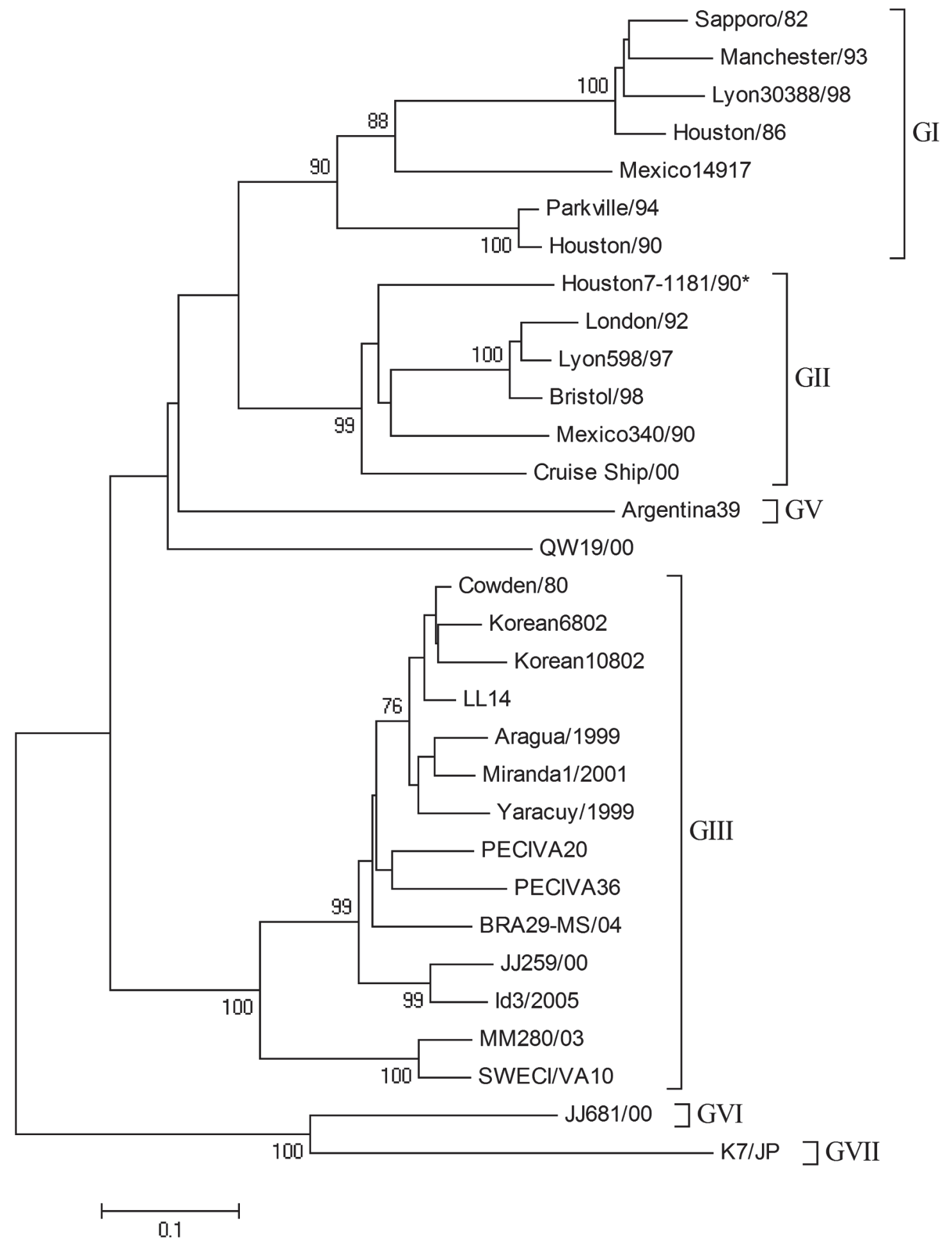

Fig.2. Phylogenetic tree reconstructed by neighbor-joining method (Kimura 2-parameter) and 1000 replicates between human, porcine and a Brazilian strain of SaV based on partial (286 nt) RdRp gene. Sequences used in the alignment were acquired from GenBank as follows accession numbers: Sapporo/82 (U65427), Manchester/93 (X86560), Lyon30388/98 (AJ251991), Houston/ 86 (U95643), Mexico14917 (AF435810), Parkville/94 (U73124), Houston/90 (U95644), Houston7-1181/90 (AF435811), London/ 92 (U95645), Lyon598/97 (AJ271056), Bristol/98 (AJ249939), Mexico340/90 (AF435809), Cruise ship/00 (AY157863), Argentina39 (AF405715), QW19/02 (AY826424), Cowden (AF182760), LL14 (AY425671), Korean6802 (AY289186), Korean10802 (AY289188), Aragua/1999 (AY633967), Miranda1/2001 (AY633964), Yaracuy/1999 (AY633966), BRA29-MS/04 (EF183480), PECIVA36 (AY615805), PECIVA20 (AY615804), JJ259/00 (AY826423), Id3/2005 (DQ383274), MM280/03 (AY823308), SWECl/ VA10 (AY615807), JJ681/00 (AY974192) and K7/JP (AB221130). Sapovirus genogroups are indicated. *GIV strain 


\section{CONCLUSION}

This is the first description of the presence of SaV in stool samples of piglets in Brazil. The detection of the virus in other countries, including South-American ones, is an important indicative that the virus is widespread. In this study, one Brazilian virus was classified as GIII member based on the similarity with Cowden strain, which causes small intestinal villous atrophy and clinical signs of enteric disease in experimental inoculated gnotobiotic pigs. In summary, these results increase the number of viruses potentially present in feces of piglets in Brazilian swine farms. Further studies are needed to understand the epidemiology of the SaV infection in Brazil, and the possible role of these infections in enteric disease and diarrhea in piglets.

Acknowledgements.- To Dr. J.P. Gagliardi Leite (Fundação Oswaldo Cruz, Rio de Janeiro, Brazil) for providing norovirus positive fecal sample, and to the Brazilian Institutes CNPq, CAPES, Finep and Fundação Araucária for financial support. A.A. Alfieri and A.F. Alfieri are recipients of CNPq fellowships.

\section{REFERENCES}

Alfieri A.A., Parazzi M.E., Takiuchi E., Médici K.C. \& Alfieri A.F. 2006. Frequency of group A rotavirus in diarrhoeic calves in Brazilian cattle herds, 1998-2002. Trop. Anim. Health Prod. 38:521-526.

Flynn W.T., Saif L.J. \& Moorhead P.D. 1988. Pathogenesis of porcine enteric calicivirus-like virus in four-day-old gnotobiotic pigs. Am. J. Vet. Res. 49:819-825.

Farkas T., Zhong W.M., Jing Y., Huang P.W., Espinosa S.M., Martinez N., Morrow A.L. Ruiz-Palacios G.M., Pickering L.K. \& Jiang X. 2004. Genetic diversity among sapoviruses. Arch. Virol. 149:1309-1323.

Green K.Y., Ando T., Balayan M.S., Berke T., Clarke I.N., Estes M.K., Matson D.O., Nakata S., Neill J.D., Studdert M.J. \& Thiel H.J. 2000. Taxonomy of the caliciviruses. J. Infect. Dis. 181:322-330.

Guo M., Chang K.O., Hardy M.E., Zhang Q., Parwani A.V. \& Saif L.J.
1999. Molecular characterization of a porcine enteric calicivirus genetically related to Sapporo-like human caliciviruses. J. Virol. 73:9625-9631.

Hansman G.S., Takeda N., Oka T., Oseto M., Hedlund K.O. \& Katayama K. 2005. Intergenogroup Recombination in Sapoviruses. Emerg. Infect. Diseases 11:1916-1920.

ICTVdB. The Universal Virus Database, version 4. <http:// www.ncbi.nlm.nih.gov/ICTVdb/ICTVdb/>. Access in: 15 jun. 2007.

Jiang X., Huang P.W., Zhong W.M., Farkas T., Cubitt D.W. \& Matson D.O. 1999. Design and evaluation of a primer pair that detects both Norwalk- and Sapporo-like caliciviruses by RT-PCR. J. Virol. Methods 83:145-154.

Kapikian A.Z., Wyatt R.G., Dolin R., Thornhill T.S., Kalica A.R. \& Chanock R.M. 1972. Visualization by Immune Electron Microscopy of a 27-nm Particle Associated with Acute Infectious Nonbacterial Gastroenteritis. J. Virol. 10:1075-1081.

Katayama K., Miyoshi T., Uchino K., Oka T., Tanaka T., Takeda N. \& Hansman G.S. 2004. Novel Recombinant Sapovirus. Emerg. Infect. Diseases 10:1874-1876.

Kim H.J., Cho H.S., Cho K.O. \& Park N.Y. 2006. Detection and molecular characterization of porcine enteric calicivirus in Korea, genetically related to sapoviruses. J. Vet. Med. B, Infect. Dis. Vet. Public Health, 53:155-159.

Madeley C.R. \& Cosgrove B.P. 1976. Letter: caliciviruses in man. Lancet 1:199-200.

Martínez M.A., Alcalá A.C., Carruyo G., Botero L., Liprandi F. \& Ludert J.E. 2006. Molecular detection of porcine enteric caliciviruses in Venezuelan farms. Vet. Microbiol. 116:77-84.

Reuter G., Bíró H. \& Szücs G. 2007. Enteric caliciviruses in domestic pigs in Hungary. Arch. Virol. 152:611-614.

Schuffenecker I., Ando T., Thouvenot D., Lina B. \& Aymard M. 2001. Genetic classification of "Sapporo-like viruses". Arch. Virol. 146:21152132.

Wang Q.W., Han M.G., Funk J.A., Bowman G., Janies D.A. \& Saif L.J. 2005. Genetic diversity and recombination of porcine sapoviruses. J. Clin. Microbiol. 43:5963-5972.

Yin Y., Tohya Y., Ogawa Y., Numazawa D., Kato K. \& Akashi H. 2006. Genetic analysis of calicivirus genomes detected in intestinal contents of piglets in Japan. Arch. Virol. 151:1749-1759. 